pp. $74-80$, April 2020

\title{
Tapioca Waste-Methyl Methacrylate Irradiation for Biodegradable Plastic Raw Materials
}

\author{
Akhmad Rasyid Syahputra*, Tita Puspitasari, Santoso Prayitno, and Ade Lestari Yunus \\ Center for Isotopes and Radiation Applications, National Nuclear Energy Agency (BATAN), Lebak \\ Bulus, South Jakarta, 12440. Indonesia
}

*Corresponding author : akhmadrasyid@,batan.go.id

\begin{tabular}{|c|c|}
\hline$A R T I C L E I N F O$ & Abstract \\
\hline Revised date : 25 February 2020 & $\begin{array}{l}\text { Nuclear technology can be applied not only as energy (electricity) but also in } \\
\text { industry as an initiator on polymer reaction. The polymer reaction can combine } \\
\text { two monomers, as an example, tapioca waste and methyl methacrylate, to make } \\
\text { biodegradable plastics. Tapioca waste is used due to its biodegradability } \\
\text { properties. Tapioca waste gel is formed by adding an equal aqua dest ratio to waste } \\
\text { weight. After gel formed, several concentrations of methyl methacrylate (w/w) is } \\
\text { added to the gel then packed into ampules. Using the Co- } 60 \text { gamma irradiation } \\
\text { source, the gel is irradiated at } 5 \text { kGy absorbed dose. Glycerol as a plasticizer is } \\
\text { added to the gel to increase polymer flexibility. To analyze its mechanical } \\
\text { properties, firstly, we need to mold the samples using a pressurized-hot press } \\
\text { machine. Then added methyl methacrylate at varying doses. The specimen is } \\
\text { tested by analyzing tensile strength characteristics (ASTM D638-14). Fabrication } \\
\text { of biodegradable plastic-based packaging by using starch has an increase in the } \\
\text { mechanical and thermal properties. }\end{array}$ \\
\hline \multicolumn{2}{|l|}{$\begin{array}{l}\text { Available online at : } \\
\text { https://doi.org/10.14203/jkti.v21i2.430 }\end{array}$} \\
\hline \multirow{2}{*}{$\begin{array}{l}\text { Keywords: } \\
\text { Irradiation, polymer, tapioca waste, } \\
\text { methyl methacrylate, biodegradable } \\
\text { plastic }\end{array}$} & \\
\hline & $\begin{array}{l}\text { (C) } 2020 \text { Indonesian Journal of Applied Chemistry. This is an open access article under the } \\
\text { CC BY-NC-SA license (https://creativecommons.org/licenses/by-nc-sa/4.0/). }\end{array}$ \\
\hline
\end{tabular}

\section{INTRODUCTION}

Plastic is always present in every human need. The use of plastics is increasing rapidly because plastics have many applications such as 74 | "Tapioca Waste-Methyl Methacrylate Irradiation...": Akhmad Rasyid Syahputra, et.al. packaging, and use for several automotive parts. The use of plastic is vital to the life of the community because of its "long-last" character [1]. The plastic raw material is generally still 
derived from petroleum that is not naturally degraded. After the useful life is over, the waste heap becomes an environmental problem [2]. Conventional plastic derived from petroleum is very difficult to degrade, and the whole process to run out takes up to 50 years [3]. One alternative to overcome these problems is to make plastics from natural materials so that they are easily degraded (biodegradable) or environmentally friendly [4]. Environmentally friendly plastics are currently needed to overcome environmental problems because of its easily degraded character. The making of environmentally friendly plastics has been investigated by combining natural polymers with synthetic polymers [5]. Biodegradable plastic can be made from materials that contain starch, such as cassava. The Center for Agricultural Data and Information Systems at the Ministry of Agriculture stated that the surplus of cassava production in Indonesia until 2018 was 923.85 thousand tons [6].

Cassava is a raw material for tapioca production. In the tapioca production process, 1 ton of cassava is produced $250 \mathrm{~kg}$ of cassava flour and $114 \mathrm{~kg}$ of cassava solid waste commonly referred to as tapioca waste. Tapioca waste still contains $45-65 \%$ starch, and some have even examined $67.8 \%$ [7]. The utilization of tapioca waste is currently only limited to animal feed or disposed of as waste. Even though with high carbohydrate content, around 65-90\% with $16 \%$ amylose and $84 \%$ amylopectin content, tapioca waste can be used as an ingredient in making biodegradable plastics. Biodegradable plastics are made from agro polymers [8] such as starch, lignin, pectin, chitin, and natural rubber. The research used tapioca waste and chitosan as trunk polymers and glycerol as the plasticizer. The result showed there is no effect from chitosan addition to tapioca waste mechanical properties but could increase its biodegradability.
There are also biodegradable plastics made from microorganisms such as polyhydroxyalkanoate [9], polyhydroxybutyrate [10], and polyhydroxy butyrate-hydroxy valerate copolymers [11]. Biodegradable plastic can also be synthesized from its monomer derivatives, such as polylactate. Biodegradable plastics derived from by-products of petrochemical processes such as polycaprolactone, aromatic and aliphatic polyester copolymers, and their homopolymers [12].

MMA is used as a reinforcing agent, thus making MMA-g-starch more easily formed/printed. The aim of this research is to develop environmentally friendly plastic based on tapioca waste and methyl methacrylate 5,10 , $15,20,25$ and 30 grams (w/w) using a gammaray irradiation so that it has optimum mechanical properties. The gamma-ray can accelerate the polymerization reaction between tapioca waste and MMA without add any crosslinker/grafting agent to the solution.

\section{EXPERIMENTAL}

\subsection{Materials}

Tapioca waste was collected from the tapioca factory in Ciluar, Bogor City, Indonesia. This research utilizes a technical methyl methacrylate monomer (hot curing). Glycerol is used generally to biodegradable plastic films to modify properties such as water sorption, mechanical properties, and glass transition temperature.

\subsection{Methods}

Tapioca waste is dissolved with distilled water at $80^{\circ} \mathrm{C}$ using a hot plate stirrer to form a paste. MMA is added to the paste in a hot state. Surfactant is added to the solution to make MMA and tapioca waste mixed in distilled water. MMA concentration was varied at 5, 10, 15, 20, 25 and 30 grams $(\mathrm{w} / \mathrm{w})$. This variation aims to find out the optimal point of MMA addition can 
improve the mechanical properties of MMA-gstarch. The sample is chilled and then packed in bottles of Polyethylene Terephthalate (PET) and irradiated using simultaneous Co-60 y-ray sources at an absorbed dose of $5 \mathrm{kGy}$ at 1.97 $\mathrm{kGy} / \mathrm{h}$ dose rate.

After irradiation, the sample was extracted using acetone to remove homopolymers, and the degree of copolymerization (DC) was calculated to determine the optimal concentration of MMA addition. The degree of copolymerization is calculated using the equation:

$D C=\left(W_{2}-W_{1}\right) / W_{0} \times 100 \%$

Where

$\mathrm{DC}=$ degree of copolymerization (\%),

$\mathrm{W}_{2}=$ the dry weight of the sample after copolymerization $(\mathrm{g})$,

$\mathrm{W}_{1}=$ the dry weight of the sample before copolymerization $(\mathrm{g})$, and

$\mathrm{W}_{0}=$ the weight of methyl methacrylate $(\mathrm{g})$.

Then the sample is dried and pressed using hot press hydraulics. Before hot-pressed by hydraulics machine, glycerol $5 \mathrm{~mL}$ is added to copolymer as a plasticizer to increase the flexibility of copolymer. The hot-pressed machine is set up at pressure $110 \mathrm{~kg} / \mathrm{cm}^{2}$ for 5 min. The mechanical properties (tensile strength and elongation at break) of the composites formed were analyzed using the Universal Testing Machine (UTM) using the ASTM D63814 methods.

\section{RESULT AND DISCUSSION}

\subsection{Optimum Monomer Concentration}

Tapioca waste used for this study was 20 grams each. The reaction of copolymerization is $5 \mathrm{kGy}$ absorbed dose. The absorbed dose is a minimal dose that can affect both degraded and cross-linked polymers. When tapioca waste containing starch is given $5 \mathrm{kGy}$ doses, it will produce free radicals which will modify the structure of starch. Viscosity will decrease when starch is given a higher dose, which will cause the starch to increase in solubility and acidity. The change in viscosity is caused by the degradation of starch structure because influenced by gamma irradiation, which causes oxidative degradation [13]. DC valuesare obtained after soxhlet extraction using acetone for 24 hours.

Table 1. Degree of copolymerization tapioca waste-methyl methacrylate

\begin{tabular}{llll}
\hline $\mathbf{W}_{\mathbf{0}}(\mathbf{g})$ & $\mathbf{W}_{\mathbf{1}}(\mathbf{g})$ & $\mathbf{W}_{\mathbf{2}}(\mathbf{g})$ & $\mathbf{D C}(\mathbf{\%})$ \\
\hline 0 & 20 & 20.0003 & - \\
\hline 5 & 20 & 20.6878 & 13.7560 \\
\hline 10 & 20 & 22.3365 & 23.3650 \\
\hline 15 & 20 & 25.3374 & 35.5827 \\
\hline 20 & 20 & 29.7741 & 48.8705 \\
\hline 25 & 20 & 32.0173 & 48.0692 \\
\hline 30 & 20 & 34.5038 & 48.3460 \\
\hline
\end{tabular}

DC value is the difference between the dry weight after and before the copolymerization process compared to the monomer weight, which added to tapioca waste.

Table 1 shows that the greater the addition of $\mathrm{x}$ monomers, the greater the degree of copolymerization obtained. The addition of $20 \mathrm{~g}$ monomers indicates the highest DC value. It means that it has a ratio of $100 \%$ to the weight of tapioca waste. The addition of $20 \mathrm{~g}$ monomers has an average DC value of 27-73\% higher compared to the others additions. Soxhlet extraction is usually used to separate components that have opposite hydrophobicity properties. In all procedures that are used to isolate the grafted polymer, there will always be a part of the monomer removed in the 76 | "Tapioca Waste-Methyl Methacrylate Irradiation...": Akhmad Rasyid Syahputra, et.al. 
copolymerization process. Some grafts contain mostly starch and they are not hydrophobic enough to be combined with synthetic polymers [14].

The addition of monomers above $20 \mathrm{~g}$ or more than $100 \%$ by weight of tapioca indicates that there is no significant increase in the degree of copolymerization. Data shows that the maximum limit of the addition of monomers above $100 \%$ will only form MMA homopolymers, as seen from $\mathrm{DC}$ the addition of $25 \mathrm{~g}$ and $30 \mathrm{~g}$ monomers results in DC, which is approximately equal to the addition of $100 \%$ tapioca weight $(20 \mathrm{~g}$ MMA). Monomer ratio of 1: 1 or $100 \%$ by weight of starch (in this study tapioca waste), the conversion to the copolymer reaches maximum results. If the monomer is added more than 100 $\%$, the DC will go down. The increasing concentration of the monomer also increases the diffusion within the monomer in tapioca waste so that increasing the DC of the copolymer. Also, high monomer concentrations are suitable for forming complexes (receptor-contributor) between tapioca waste and its monomers [15]. Hence, the optimum monomer concentration from this study is 1:1 (100\% monomer addition, $20 \mathrm{~g}$ ). Even the simultaneous irradiation can be done easier, there is loss of control at high monomer consumption. The maximum addition of methyl methacrylate (100\%) only give less than $50 \%$ of DC. Therefore, we assumpe that an active backbone site [16] as a result of irradiation can only be polymerized with less than $100 \%$ MMA.

\subsection{FTIR Characterization}

The FTIR spectra of irradiated MMA-gstarch using glycerol as a plasticizer are shown in Figure 1. It reveals that the FTIR spectra of starch (tapioca waste) show a typical spectrum with three major peaks region marked as 1 (3700-2700 $\left.\mathrm{cm}^{-1}\right), 2\left(2100-1000 \mathrm{~cm}^{-1}\right)$, and 3 $\left(900-450 \mathrm{~cm}^{-1}\right)$. As it can be seen in the spectrum of tapioca (P1), the presence of $\mathrm{O}-\mathrm{H}$ group $\left(3285,7 \mathrm{~cm}^{-1}\right)$, confirmed by the presence of band at $1420,7 \mathrm{~cm}^{-1}$ ) that suggest the existence of the C-C group. The appearance of the absorption band at $2930,9 \mathrm{~cm}^{-1}$ is confirmed by the presence of band at $1345,7 \mathrm{~cm}^{-1}$. Bending vibration of $\mathrm{C}-\mathrm{C}$ at the tapioca spectrum can be observed at $1012,7 \mathrm{~cm}^{-1}$, whereas stretching vibration of C-O appears at $1150,4 \mathrm{~cm}^{-1}$. These band adsorptions was came from glucose unit of tapioca waste [17]. FTIR spectrum of MMA shows $\mathrm{C}=\mathrm{C}$ group band at $1640,6 \mathrm{~cm}^{-1}$, whereas $1275 \mathrm{~cm}^{-1}$ linked with $\mathrm{C}-\mathrm{O}-\mathrm{C}$ from ester. Group of $\mathrm{C}=\mathrm{C}$ alkene and $\mathrm{C}=\mathrm{O}$ carbonyl can be seen at $3430 \mathrm{~cm}^{-1}$ and $1729,7 \mathrm{~cm}^{-1}$.

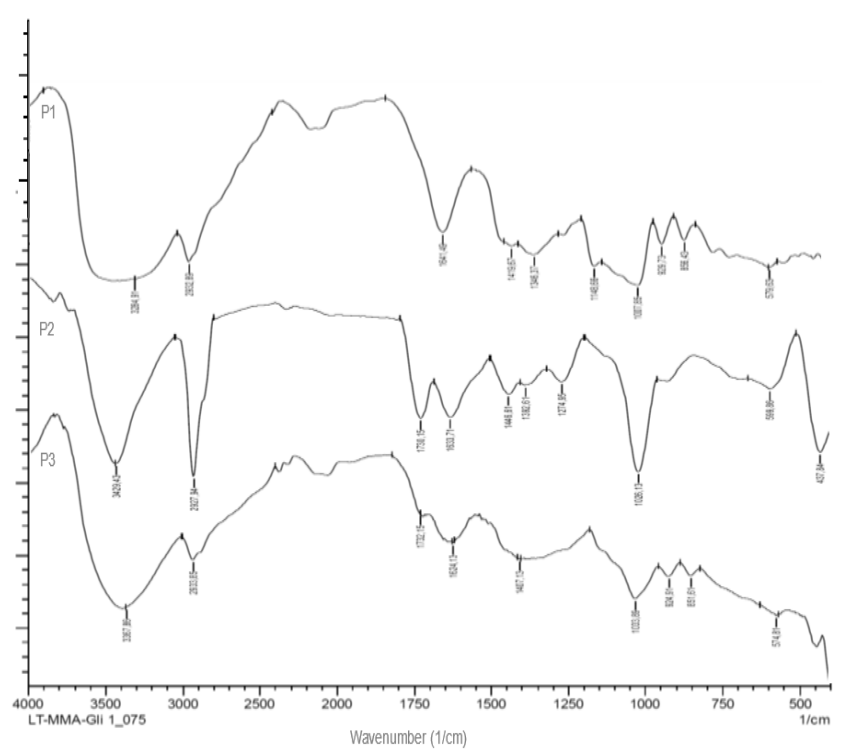

Fig. 1. FTIR spectra of tapioca (P1), MMA (P2), and irradiated MMA-g-starch (P3).

FTIR spectrum of irradiated MMA-g-starch (P3) shows a shift at the $\mathrm{C}=\mathrm{O}$ carbonyl group which found in MMA FTIR spectrum (P2). The $\mathrm{C}=\mathrm{O}$ group adsorption from MMA is $1729,7 \mathrm{~cm}^{-}$ ${ }^{1}$ but in the Fig. 1 (P2) $\mathrm{C}=\mathrm{O}$ group adsorption shifted to $1712,8 \mathrm{~cm}^{-1}$. This shift is suggested as addition of the polymerization reaction to the $\mathrm{C}=\mathrm{C}$ bond at MMA so that the conjugated double bond is defected and causes energy change to $\mathrm{C}=\mathrm{C}$ stretch [18]. 
pp. $74-80$, April 2020

\subsection{Mechanical Properties}

The pressing process for tapioca waste-MMA copolymer is needed to support the mechanical properties test to have a standard specimen for ASTM D368. Before pressed by a hot press hydraulics machine, glycerol is added to copolymer as a plasticizer to increase the flexibility of copolymer because glycerol has better efficiency than sorbitol to modify the mechanical properties of copolymer [19]. The tensile strength of the plastic containing $20 \mathrm{~g}$ of monomer is about 20 times higher than $5-15 \mathrm{~g}$ monomer addition. This is due to the higher addition of methyl methacrylate so that the mechanical properties obtained in copolymer tapioca waste-methyl methacrylate is higher. MMA and tapioca waste mixture can be crosslinked by $\gamma$ irradiation so increase the tensile strength of the graft [20].

Based on the results it can be concluded that the addition of methyl methacrylate can affect the tensile strength of a specimen. The effect of adding methyl methacrylate on tensile strength has increased and decreased under certain conditions. The more the composition of methyl methacrylate and the less tapioca waste used, the higher the tensile strength value is produced. Tensile strength (TS) test results produced with the addition of methyl methacrylate of 10.3324.78 MPa (10-30 g MMA), this corresponds to the standard criteria of the tensile strength of biodegradable plastics in Indonesia SNI 7188.7:2011 of 5-100 MPa (Requirements for biodegradable packaging materials containing starch and thermoplastic mixtures and containing degradation agents can be used as packaging materials) [21].

Elongation at break (EB) of tapioca wasteMMA was found to be simultaneously improved by the attachment of poly-MMA graft on the tapioca waste surfaces [22]. Because, graft MMA-tapioca waste is added glycerol as a plasticizer which makes graft more flexible. Many polymers pores is filled by glycerol, thus increase the graft elasticity [23]. Also, according to Xiu-Li, tapioca waste can increase the elasticity of the graft too [24]. The attachment of only $5 \mathrm{~g}$ MMA caused almost 5 times higher EB. The highest EB is at $20 \mathrm{~g}$ MMA addition, the value of its $\mathrm{EB}$ is $22-41 \%$ more efficient than any other MMA concentration. Based on the results of the mechanical test, it concluded that 20 g MMA could be considered as an optimum concentration (weight) for the increasing on the mechanical properties of tapioca waste-MMA.

Table 2. Mechanical properties of tapioca waste-co-methyl methacrylate

\begin{tabular}{ccc}
\hline Conc. MMA & TS (MPa) & EB (\%) \\
\hline 0 & 0.56 & 1.05 \\
5 & 1.96 & 4.86 \\
10 & 10.33 & 6.53 \\
15 & 18.03 & 10.41 \\
20 & 24.78 & 11.81 \\
25 & 24.23 & 11.97 \\
30 & 24.55 & 11.43 \\
\hline
\end{tabular}

\section{CONCLUSION}

Biodegradable plastic can be obtained from the copolymerization process between tapioca waste and MMA monomers using gamma-ray irradiation. Biodegradable plastic waste tapiocaMMA has tensile strength that meets the requirements of $24.78 \mathrm{MPa}$ and has an optimum elongation at break for the addition of MMA at 20-25 g.

\section{ACKNOWLEDGMENT}

We are very thankful to our expert on biodegradable plastic research, Drs. Sudradjat Iskandar who provided his expertise in this study. We are also grateful to Dewi S. Pangerteni for supporting us in the mechanical testing process. 
pp. $74-80$, April 2020

\section{REFERENCES}

[1] S. L. Ezeoha, "Production of Biodegradable Plastic Packaging Film from Cassava Starch," no. August, 2017.

[2] F. A. dan R. D. K. Dwi Fibriyani, "Pengolahan Onggok Singkong sebagai Plastik Biodegradable Menggunakan Plasticizer Gliserin dari Minyak Jelantah," J. Apl. Teknol. Pangan, vol. 6, no. 2, pp. 74-77, 2017.

[3] H. K. Webb, J. Arnott, R. J. Crawford, and E. P. Ivanova, "Plastic Degradation and Its Environmental Implications with Special Reference to Poly(ethylene terephthalate)," Polymers (Basel)., vol. 5, pp. 1-18, 2013.

[4] Y. Darni and H. Utami, "Studi Pembuatan dan Karakteristik Sifat Mekanik dan Hidrofobisitas Bioplastik dari Pati Sorgum," J. Rekayasa Kim. dan Lingkung., vol. 7, no. 4, pp. 88-93, 2010.

[5] G. R. Biswas, S. B. Majee, and A. Roy, "Combination of synthetic and natural polymers in hydrogel: An impact on drug permeation," J. Appl. Pharm. Sci., vol. 6, no. 11, pp. 158-164, 2016.

[6] I. B. Suryaningrat, W. Amilia, and M. Choiron, "Current Condition of Agroindustrial Supply Chain of Cassava Products: A Case Survey of East Java, Indonesia," Agric. Agric. Sci. Procedia, 2015 .

[7] N. Musita, "Kajian Sifat Fisikokimia Tepung Onggok Industri Besar Dan Industri Kecil Study Of Physicochemical Properties Of Large Industry And Small Industry," Maj. Teknol. Agro Ind., vol. 10, no. 1, pp. 19-24, 2018.

[8] M. Rodríguez, J. Osés, K. Ziani, and J. I. Maté, "Combined effect of plasticizers and surfactants on the physical properties of starch based edible films," Food Res.
Int., 2006.

[9] P. Jambunathan and K. Zhang, "Engineered biosynthesis of biodegradable polymers," Journal of Industrial Microbiology and Biotechnology. 2016.

[10] A. Hamieh, Z. Olama, and H. Holail, "Microbial production of polyhydroxybutyrate, a biodegradable plastic using agro-industrial waste," Glob. Adv. Res. J. Microbiol., 2013.

[11] N. M. Barkoula, S. K. Garkhail, and T. Peijs, "Biodegradable composites based on flax/polyhydroxybutyrate and its copolymer with hydroxyvalerate," Ind. Crops Prod., 2010.

[12] D. Nurlita, H. Wikanastri, and M. Yusuf, "K[1] D. Nurlita, H. Wikanastri, and M. Yusuf, 'Karakteristik Plastik Biodegradable Berbasis Onggok dan Kitosan Dengan Plastisizer Gliserol,' J. Pangan dan Gizi, vol. 7, no. 2, 2017.arakteristik Plastik Biodegradable Berbasis Onggok dan Kitosan Dengan Plas," J. Pangan dan Gizi, vol. 7, no. 2, 2017.

[13] N. N. Nasir and S. A. Othman, "Gamma Radiation Effects on Biodegradable Starch Based Blend With Different Polyester: A Review," J. Adv. Res. Dyn. Control Syst., no. August, pp. 1943-1966, 2019.

[14] S. Cummings, Y. Zhang, N. Smeets, M. Cunningham, and M. A. Dubé, "On the use of starch in emulsion polymerizations," Processes, vol. 7, no. 3, 2019.

[15] R. M. Wang, X. W. Wang, J. F. Guo, Y. F. He, and M. L. Jiang, "Crosslinkable potato starch-based graft copolymer emulsion for humidity controlling coatings," Mater. Res., vol. 16, no. 6, pp. 
1246-1253, 2013.

[16] H. Atrous, F. Hosni, S. M. Danthine, and C. Blecker, "Gamma radiation induced modifications of tapioca starch," ASIAN Acad. Res. J. Multidiscip., 2016.

[17] R. Sacithraa, M. MadhanMohan, and S. Vijayachitra, "Quantitative Analysis of Tapioca Starch using FT-IR Spectroscopy and Partial Least Squares," Int. J. Comput. Appl., 2013.

[18] F. Han, D. Xiong, Q. Wang, B. Shao, and M. Chen, "Thermal properties of carboxymethylcellulose and methyl methacrylate graft copolymers," $J$. Macromol. Sci. Part B Phys., 2013.

[19] M. L. Sanyang, S. M. Sapuan, M. Jawaid, M. R. Ishak, and J. Sahari, "Effect of plasticizer type and concentration on tensile, thermal and barrier properties of biodegradable films based on sugar palm (Arenga pinnata) starch," Polymers (Basel)., vol. 7, no. 6, pp. 1106-1124, 2015.

[20] S. Iskandar, "Graft Copolymerization of Methyl Methacrylate Monomer onto Starch and Natural Rubber Latex Initiated by Gamma Irradiation," Atom Indones., vol. 37, no. 37, pp. 24-28, 2011.

[21] T. Dwi, S. Matondang, B. Wirjosentono, and D. Yunus, "Pembuatan Plastik Kemasan Terbiodegradasikan Dari Polipropylena Tergrafting Maleat Anhidrida dengan Bahan Pengisi Pati Sagu Kelapa Sawit," Valensi, vol. 3, no. 2, pp. 110-116, 2013.

[22] M. C. Li, X. Ge, and U. R. Cho, "Mechanical performance, water absorption behavior and biodegradability of poly(methyl methacrylate)-modified starch/SBR biocomposites," Macromol. Res., vol. 21, no. 7, pp. 793-800, 2013.
"PLASTIK BIODEGRADABLE BERBAHAN AMPAS SINGKONG DAN POLIVINIL ASETAT," Pros. Semin. Nas. Fis. SNF2015, vol. IV, pp. 57-62, 2015.

[24] X.-L. Wang, K.-K. Yang, Y.-Z. Wang, Z.X. Zhou, and Y.-D. Jin, "Synthesis and nuclear magnetic resonance analysis of starch-g-poly(1,4-dioxan-2-one) copolymers," J. Polym. Sci. Part Apolymer Chem. - J POLYM SCI APOLYM CHEM, vol. 42, pp. 3417-3422, Jul. 2004.

[23] N. Asni, D. Saleh, and N. Rahmawati,

80 |"Tapioca Waste-Methyl Methacrylate Irradiation...": Akhmad Rasyid Syahputra, et.al. 